\title{
PROBLEM KOMFORTU W ŚRODOWISKU MIESZKANIOWYM NA PODSTAWIE ANALIZY DWÓCH KRAKOWSKICH OSIEDLI
}

\begin{abstract}
Komfort środowiska i jego wpływ na człowieka jest problemem wielopłaszczyznowym; może więc być rozpatrywany przez pryzmat wielu dyscyplin naukowych. Dotyka zarówno problemów z zakresu gospodarki przestrzennej, jak i architektury i urbanistyki, a także socjologii. Kolejnym problemem związanym ze wskazaną tematyką jest trudność pozyskania obiektywnych wyników oceny jakości środowiska mieszkaniowego, a w konsekwencji także wniosków pozwalających na określenie zależności jakie wynikają z oddziaływania środowiska - jego elementów ożywionych i nieożywionych na człowieka. W artykule zaprezentowana została diagnoza funkcjonalno-przestrzenna wykonana dla dwóch krakowskich osiedli Olszy II i Ugorka. Projekt realizowany był przez zespół z Instytutu Projektowania Urbanistycznego Wydziału Architektury, Politechniki Krakowskiej na zlecenie Urzędu Miasta Krakowa, w ramach Pilotażowego Programu Rehabilitacji Zabudowy Blokowej na terenie Gminy Kraków. Badania eksperckie na wszystkich etapach trwania projektu wspierane były opinią mieszkańców ocenionych osiedli, którzy biorąc udział w warsztatach i organizowanych spotkaniach mieli możliwość prezentowania własnego zdania na temat zamieszkiwanego przez siebie obszaru, sposobu jego aranżacji, jego słabych i mocnych stron.
\end{abstract}

Słowa kluczowe: środowisko mieszkaniowe, komfort, diagnoza funkcjonalnoprzestrzenna, osiedle mieszkaniowe

\section{Wstęp}

Środowisko zbudowane jest tym, które towarzyszy człowiekowi niemal od zawsze. Pewnie gdybyśmy uznali, że jego oddziaływanie jest wyłącznie negatywne dziś żylibyśmy w podobnych warunkach jakie panowały w odległych czasach. Należy jednak podkreślić, że często nasze współczesne wyobrażenia o wysokiej jakości przestrzeni miejskiej są skrajnie różne. „Żyjemy w ciągłym rozdarciu pomiędzy rywalizującymi ze sobą potrzebami. Trudno zaś o impulsy bardziej sprzeczne niż zaangażowane w nieustanną przepychankę potrzeba odo-

1 Justyna Kobylarczyk, Politechnika Krakowska, Wydział Architektury, Instytut Projektowania Urbanistycznego, Katedra Kształtowania Środowiska Mieszkaniowego, Podchorążych 1, 30-084 Kraków; tel. 1262824 33; j.kobylarczyk@op.pl 
sobnienia z jednej i bliskiego kontaktu z innymi ludźmi z drugiej strony. Jak widać, pod pewnymi względami nasze pragnienia toczą ze sobą prawdziwe wojny. Potrzeba nam ożywczego i pomocnego ciepła innych osób, lecz także uzdrawiającego dotyku natury. Chcemy tworzyć więzi z ludźmi, lecz zarazem musimy czasem od nich się oddalić. Korzystamy z wygód i udogodnień, jakie niesie z sobą bliskość innych istot ludzkich, lecz bywa, że ceną, jaką przychodzi nam za to zapłacić, jest nadmiar bodźców i poczucie stłoczenia"2. Choć współczesność słusznie manifestuje wartość środowiska naturalnego to wydaje się, że w dobie tak daleko rozwiniętych technologii bez sztucznie wykreowanych uwarunkowań dziś nasze życie byłoby bardzo trudne. Środowisko sztuczne charakteryzujące się wysokim standardem w połączeniu ze światem czerpiącym $\mathrm{z}$ elementów przyrodniczych pozwala na stworzenie wizji miejsca wysokiej jakości przyjaznego człowiekowi. Należy jednak przy tym zauważyć, że zarówno środowisko ma zdolność oddziaływania na człowieka jak i człowiek ma zdolność oddziaływania na środowisko. Miejsce bowiem można uznać za żyjące tylko za sprawą jego użytkowników. Bowiem otoczenie przybiera postać jedynie scenerii - tła dla wydarzenia, którego sprawcą jest człowiek. To od niego zależy, czy odwiedzi dany punkt $\mathrm{w}$ przestrzeni miasta, czy pozwoli by popadł on w zapomnienie. Na jego decyzję wpływać mogą wszystkie te elementy, które sprawiają, że jest zapamiętywane.

Także nie zawsze jednoznacznie rozumiane jest pojęcie komfortu ${ }^{3}$, który postrzegać można w różny sposób, co uzależnione jest od wielu czynników, w tym między innymi od warunków środowiska zamieszkania oraz standardów życia jak i indywidualnych upodobań jednostki. Mimo wspomnianych trudności słownik wyrazów obcych definiuje komfort posługując się w tym celu między innymi skojarzeniami takimi jak wygoda, czy też konieczność zaspakajania potrzeb fizycznych i psychicznych człowieka, który z jednej strony czerpie z otoczenia, ale również przekazuje mu pewne wartości i cechy kształtujące jego tożsamość, przy czym trudno jest rozdzielić wpływ czynników ożywionych i nieożywionych na komfort zamieszkania. Zarówno sztuczne elementy, jak i przyrodnicze kreują bowiem w takim samym stopniu nasze środowisko życia.

Tego typu problematykę bada i rozwija wiele jednostek działających w Polsce jak i zagranicą. Polska Polityka Architektoniczna - w projekcie dokumentu Polityka jakości krajobrazu, przestrzeni publicznej, architektury skupia uwagę na problemach, których rozwiązanie pozwoliłoby na zdefiniowanie obszarów jako komfortowych, w których respektowane są społeczne potrzeby jakości środowiska zbudowanego oraz wymogi rozwoju zrównoważonego. Jako przyczyny

\footnotetext{
${ }^{2} \mathrm{CH}$. Montgomery, Miasto szcęśliwe. Jak zmieniać nasze życie, zmieniając nasze miasta, Wyscki Zamek, Kraków 2015, s.152

${ }^{3}$ O komforcie Autorka pisze między innymi [w:] J. Kobylarczyk, Ocena jakości środowiska zamieszkania $w$ wybranych miastach województwa podkarpackiego po okresie „transformacji” w pierwszej dekadzie XXI wieku, Politechnika Krakowska, Kraków 2013
} 
krytycznego stanu przestrzeni wymienia się między inny brak spójności w strukturze przestrzennej centrów miast, uniformizację przestrzeni jak i architektury kształtującej wizerunek współczesnego osiedla mieszkaniowego, niekontrolowane rozrastanie się strefy podmiejskiej, w tym rozpraszanie się zabudowy na terenach rekreacyjnych i rolniczych, niski poziom rozwiązań architektonicznych obiektów zwłaszcza na terenach wiejskich i podmiejskich, a także zaniedbanie wizualne przestrzeni publicznych służących ogółowi społeczeństwa. Wymienione zjawiska są przykładem procesów negatywnie oddziałujących na środowisko życia człowieka, których zahamowanie nie jest działaniem prostym. Wymaga bowiem uwzględnienia standardów urbanistycznych warunkujących wysoką jakość środowiska mieszkaniowego, przy uwzględnieniu konieczności jego transformacji, a wiec dostosowania się do współcześnie obowiązujących standardów życia, poniekąd zapisanych w planach zagospodarowania przestrzennego. Nie bez znaczenia pozostaje także udział społeczeństwa w podejmowaniu wspólnych dyskusji, planów i działań zmierzających do poprawy warunków życia. Ze względu na zróżnicowania występujące w różnych regionach oraz ich indywidualne uwarunkowania niezwykle trudno jest wskazać spójne dla różnych obszarów elementy, wskaźniki i czynniki odpowiadające za komfort zamieszkania. Jest to więc wciąż aktualny temat badawczy wymagający opracowania uniwersalnej metody oceny jakości środowisk mieszkaniowych. Między innymi Komisja Europejska podjęła próbę skonstruowania dokumentu Interim Report (2002), w którym przedstawiła dziesięć grup problemowych mających wpływ na sposób postrzegania środowiska zamieszkania przez jego mieszkańców oraz na oferowane przez niego warunki życia. W tym jako najważniejszy czynnik uznano satysfakcję mieszkańców z mieszkania w danej lokalnej społeczności oraz możliwość udziału na rzecz poprawy klimatu, w tym zmniejszenia zanieczyszczenia powietrza. Jako współcześnie ważny problem uznano nadmierne wykorzystywanie indywidualnych środków transportu z uwagi na trudności w zakresie sieci powiązań komunikacyjnych przestrzeni przy wykorzystaniu zbiorowych środków transportu. Prowadzi to między innymi do pogorszenia jakości powietrza, zagrożenia hałasem oraz rosnącej intensywności ruchu samochodowego, co poza oczywistymi problemami rodzi także szereg poważnych zagrożeń, na które między innymi narażone są dzieci - zwłaszcza te, które samodzielnie pokonują drogę do i ze szkoły. Problemem współczesności trwale wpisanym w strukturę przestrzenną obszarów zamieszkania jest także ograniczona dostępność zielonych przestrzeni publicznych i usług oraz produktów zrównoważonych. Z rozwojem zrównoważonym związane jest również zrównoważone zarządzanie przestrzeniami środowiska zamieszkania przez lokalne władze i lokalny biznes oraz zrównoważone użytkowanie terenu.

Podobne starania dotyczące opracowania metody oceny jakości środowiska zamieszkania podjął zespół z Katedry Kształtowania Środowiska Mieszkaniowego sporządzając diagnozę funkcjonalno - przestrzenną dla dwóch krakowskich osiedli mieszkaniowych - Olszy II i Ugorka. 


\section{Analiza przykładu}

Diagnoza przestrzenno - funkcjonalna zrealizowana dla dwóch krakowskich osiedli Olszy II i Ugorka ${ }^{4}$ (rys. 1 i 2) stanowi nie tylko opis wyników szeregu podjętych na wskazanym terenie analiz, ale także stanowi próbę skonstruowania uniwersalnej metody oceny środowiska zamieszkania, w którym dominuje wielorodzinna zabudowa blokowa z lat 70-tych i 80-tych, bazującej na wieloletnich badaniach powiązanych $\mathrm{z}$ prezentowaną tematyką jak i własnych spostrzeżeń dotyczących skali i sposobu oddziaływania środowiska zbudowanego na człowieka.

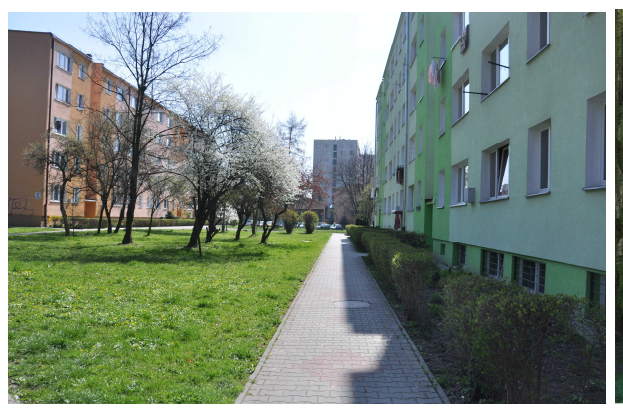

Rys.1. Fragment osiedla Olsza II

Fig.1. Part of the estate Olsza II

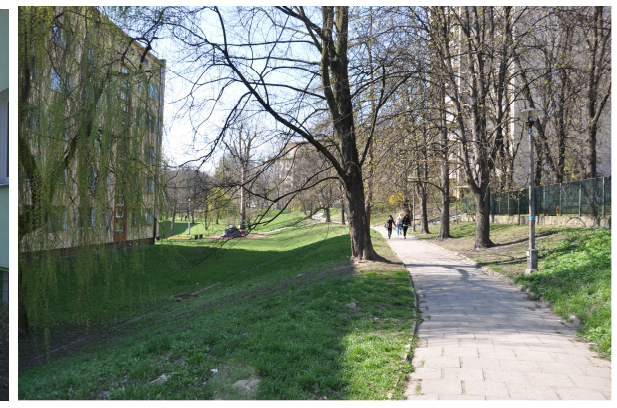

Rys.2. Fragment osiedla Ugorek [1]

Fig.2. Part of the estate Ugorek [1]

Podjęty w 2014 roku projekt naukowo- badawczy został zrealizowany w ramach Pilotażowego Programu Rehabilitacji Zabudowy Blokowej na terenie Gminy Kraków. Projekt realizowany był na zlecenie i przy jednoczesnym udziale Urzędu Miasta Krakowa (Wydział Rozwoju Miasta). Partnerami ponadto byli: Instytut Socjologii Uniwersytetu Jagiellońskiego oraz Stowarzyszenie Pracowni Obywatelskiej. Zespół z Politechniki Krakowskiej, Wydziału Architektury, Instytutu Projektowania Urbanistycznego, Katedry Kształtowania Środowiska Mieszkaniowego tworzyli: Prof. dr hab. inż. arch. Grażyna Schneider-Skalska ekspert projektu, dr hab. inż. arch. Justyna Kobylarczyk, prof. PK - kierownik projektu, dr inż. arch. Patrycja Haupt, dr inż. arch. Kinga Racoń-Leja, mgr inż. arch. Wojciech Sumlet, mgr inż. arch. Paweł Tor oraz studenci ze Studenckiego Koła Naukowego Projektowania Zrównoważonego.

Celem projektu było badanie powiązań jakie zachodzą między środowiskiem a człowiekiem oraz określenie, które elementy środowiska mieszkaniowego odpowiadają za jego komfort biorąc pod uwagę między innymi współczesne trendy, w tym modę na zdrowy styl życia, przy jednoczesnym starzeniu się

\footnotetext{
${ }^{4}$ J.Kobylarczyk, G. Schneider-Skalska, P. Haupt, K. Racoń-Leja, W. Sumlet, P. Tor, Studenckie Koło Naukowe Projektowania Zrównoważonego, Diagnoza funkcjonalno-przestrzenna osiedli: Olsza Iii Ugorka, Politechnika Krakowska, Kraków 2014
} 
społeczeństwa. Wymagało to głębokiej i interdyscyplinarnej analizy problematyki, oraz poznania specyfiki wybranych do badań osiedli i skonstruowania metody ich oceny umożliwiającej pozyskanie obiektywnych wniosków, co w przypadku jakości środowiska jest bardzo trudne ze względu na oczywiste zaangażowanie sfery emocjonalnej każdego z nas. Zwłaszcza, gdy z ocenianym obszarem czujemy się związani (jest to nasze miejsce zamieszkania, naszych bliskich, bądź z różnych względów czujemy sentyment do analizowanego miejsca).

Analiza dotyczyła dwóch skali - skali mikro oraz makro. W obu przypadkach polegała ona na ocenie poszczególnych elementów, które pozwoliłyby na wyznaczenie pożądanych cech osiedli pozwalających na określenie ich mianem „,̇yjących”, wygodnych, zdrowych, a więc komfortowych, stwarzających możliwość realizowania preferowanego przez użytkowników stylu życia, który w dużej mierze podyktowany jest nowymi tendencjami charakterystycznymi dla rozwoju zrównoważonego. Powiązane są one $\mathrm{z}$ wielkościami fizycznymi, a więc z odległościami i proporcjami (skala obiektów i dystans między nimi), wartościami wizualnymi, charakterem przestrzeni, w tym jej czytelnością oraz elementami kształtującymi poczucie intymności i spokoju oraz bezpieczeństwa. Osobnym zbiorem elementów podlegających ocenie są elementy przyrodnicze oceniane także ze względu na ich dostępność. Wszystkie wybrane do badań grupy problemowe powiązane ze sztucznym i naturalnym środowiskiem wyłoniły w efekcie końcowym atuty i główne problemy osiedli oraz pozwoliły skonstruować propozycje zmian w celu stworzenia pożądanego stanu środowiska mieszkaniowego - środowiska komfortowego. Diagnoza oparta była na zasadach partycypacji społecznej, co umożliwiło dokonanie porównania wyników badań własnych z opinią mieszkańców, a więc poznania opinii i spostrzeżeń użytkowników analizowanych obszarów.

Skala makro polegała na ocenie metodą gabinetową poszczególnych czynników mających wpływ na sposób postrzegania środowiska mieszkaniowego w odniesieniu do miasta. Oceniono między innymi uwarunkowania komunikacyjne - możliwość powiązań komunikacyjnych analizowanych obszarów z innymi lokalizacjami Krakowa. Kolejnym badanym czynnikiem były uwarunkowania społeczno - demograficzne. Szczególnie istotne dla oceny obszarów mieszkaniowych wydawało się ustalenie w jakim wieku są mieszkańcy Olszy II i Ugorka, biorąc przy tym pod uwagę, że inne potrzeby, wymagania i preferencje mają osoby młode, a inne osoby starsze. Także tą metodą oceniono bezpieczeństwo wskazanych lokalizacji porównując rodzaj i częstotliwość danych wykroczeń mających miejsce w badanych osiedlach i w innych lokalizacjach miasta.

Analiza makro sporządzona została przez studentów na podstawie "Wielokryterialnej analizy dziewiętnastu osiedli zabudowy blokowej położonych na terenie gminy miejskiej Kraków", opublikowanej przez Urząd Miasta Krakowa. Badania czynników mikro oparte zostały na analizie urbanistycznej. Dodatkowo stworzone zostały formularze do wywiadów, które nie zostały wykorzystane do badań ankietowych przez zespół z Wydziału Architektury Politechniki Krakowskiej. 
Analiza urbanistyczna jako metoda badań prowadzonych $\mathrm{w}$ terenie z uwzględnieniem pomiarów inwentaryzacyjnych pozwoliła na ocenę uwarunkowań charakteryzujących osiedle Olsza II i Ugorek jako:

- żyjące (zapewniające dostęp do programu usług, punktów aktywności oraz miejsc spotkań, przestrzeni lubianych),

- wygodne ze względu na czytelny układ funkcjonalno - przestrzenny, łatwą dostępność do usług oraz punktów i przestrzeni komunikacyjnych,

- zdrowe - sprzyjające kondycji psycho-fizycznej człowieka ${ }^{5}$ (rys.3).

Sformułowane przez zespół opracowujący diagnozę osiedli trzy grupy problemowe dowiodły $\mathrm{w}$ jakim stopniu wybrany obszary zamieszkania można uznać za wysokiej jakości.

Wpływ na ocenę komfortu obszarów zamieszkania mają więc zarówno elementy kształtujące „naturalne” jak i sztuczne środowisko. Wśród najważniejszych elementów badanych uznano różnorodność programu usług, które pozwalają na traktowanie miejsca zamieszkania jako atrakcyjnego także wciągu dnia, co stanowi zaprzeczenie wizerunku ,osiedla sypialni”. Ważne także w celu zachowania żywotności obszaru są rozwiązania komunikacyjne (powiazania ścieżek spacerowych, rowerowych, lokalizacja przystanków autobusowych, itd.) i co stanowi część środowiska ożywionego usytuowanie i samo istnienie przestrzeni zielonych. Osiedle by żyć musi także zawierać w swoim zasięgu przestrzenie chętnie odwiedzane przez mieszkańców, z którym chcą się identyfikować, które budują zjawisko tożsamości miejsca.

Środowisko mieszkaniowe komfortowe to także miejsce wygodne, a więc charakteryzujące się funkcjonalnością rozwiązań i bezpieczeństwem oraz łatwą dostępnością do poszczególnych punktów usługowych, czytelnością układu przestrzennego miejsca i jego przejrzystością. Sprzyja mu ,jasność” granic między poszczególnymi strefami obszaru wynikającymi z podziału własności (przestrzeń publiczna, społeczna, prywatna) bądź podziału wynikającego z różnorodności funkcji (miejsca pracy, zamieszkania i wypoczynku).

Osiedle wygodne zapewnia także czytelne powiązanie obszaru z siecią transportu publicznego dbając o ograniczenia ruchu wewnątrz obszaru zabudowy mieszkaniowej oraz stan techniczny jak i wyposażenie ciągów komunikacyjnych.

Kolejną grupę problemową stanowią elementy i czynniki pozwalające na zdefiniowanie obszaru jako zdrowego, co także mieści się w znaczeniu komfortowe środowisko mieszkaniowe. Zdrowiu fizycznemu mieszkańców sprzyja obecność przestrzeni zielonych - obszarów rekreacji, ale także obiektów sportowych. Nie bez znaczenia pozostaje program użytkowy przestrzeni wspólnych, który zapewniać powinien strefę aktywności fizycznej jak i strefę wypoczynkową. Na samopoczucie psychiczne i mentalne wpływa ocena zabudowy mieszkaniowej -

\footnotetext{
${ }^{5}$ Zdrowe środowisko mieszkaniowe interpretuje G. Schneider-Skalska w swojej pracy, Design a healthy housing environment. Selected problems, Lap Lambert Academiic Publishing, Saarbrücken 2011
} 
jej skala, układ oraz intensywność, co ma znaczenia dla poczucia prywatności, oraz wzmocnienia więzi sąsiedzkich. Pozytywne emocje wyzwalają wartości estetyczne oraz dopasowanie.

Na jakość środowiska zamieszkania wpływa także odpowiednia organizacja przestrzeni wspólnej pozwalająca na zawiązanie relacji sąsiedzkich w celu poczucia spójności społecznej. Odpowiada za nią:

- dostosowanie do potrzeb osób niepełnosprawnych;

- stopień otwartości przestrzeni społecznej (utrudniona dostępność - obszar dostępny jedynie dla mieszkańców) - dostępność wnętrza społecznego - półotwarta konfiguracja wnętrz urbanistycznych.

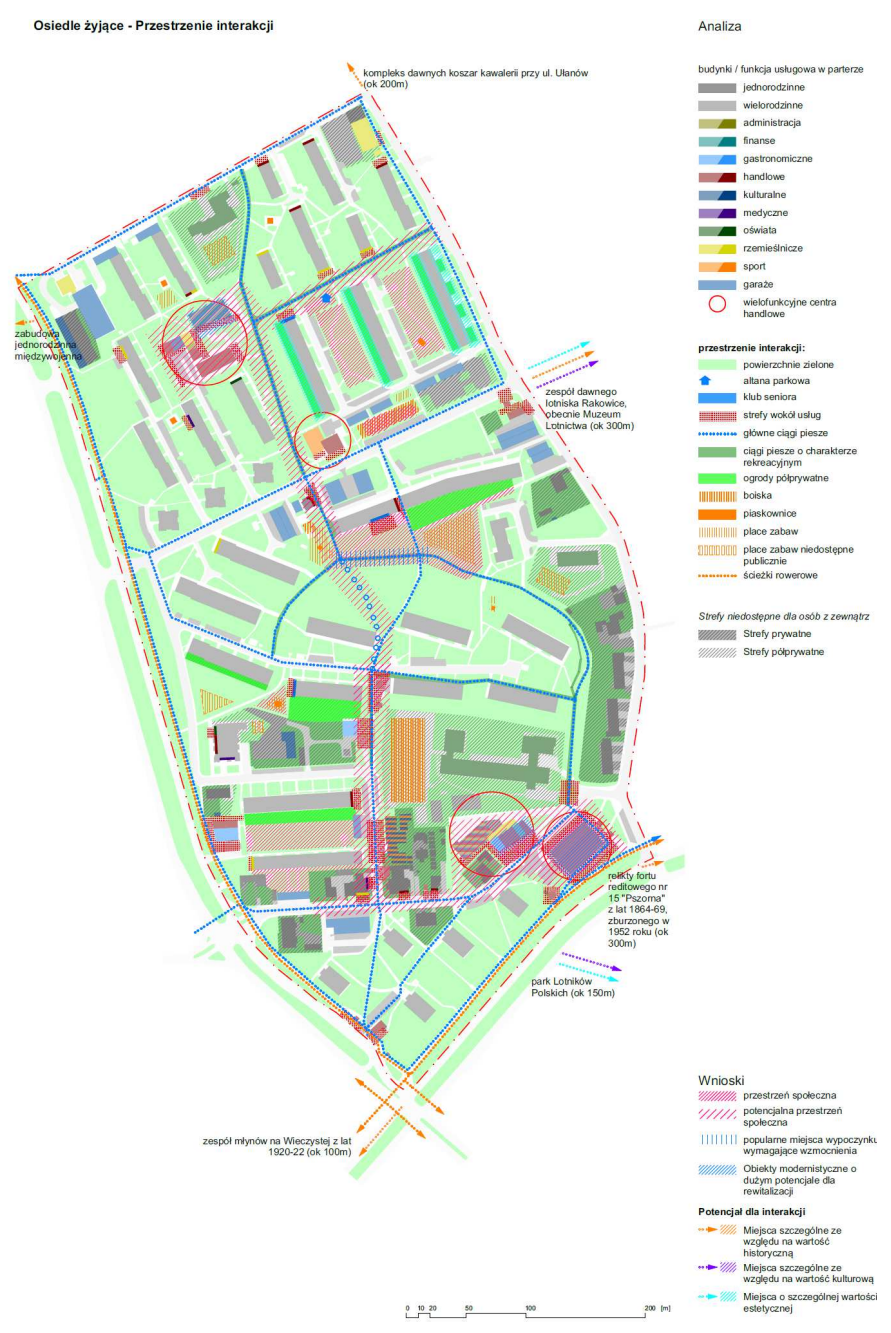

Rys. 3. Przykład schematu przestrzenno-funkcjonalnego wykonanego dla Osiedla Ugorek na podstawie analizy urbanistycznej

Fig.3. Example scheme spatio-functional made for estates Ugorek based on the analysis of urban 


\section{Uwagi końcowe}

„Przez całe życie odczuwamy ciągłą potrzebę zbierania nowych wiadomości o ludziach, o tym, co nowego się dzieje i o otaczających nas społecznościach. Informacje te zbiera się tam, gdzie są ludzie i dlatego jest to często wspolna przestrzeń miejska"6.

Przyjęta metoda badań pozwoliła na wykazanie w jakim stopniu elementy sztucznego środowiska mogą wpływać na komfort zamieszkania współczesnego człowieka. Jako podstawową metodę badań przyjęto analizę czynników „mikro” pozwalającą ocenić zastane sąsiedztwa dwóch osiedli - Olszy II i Ugorka jako: żyjące, wygodne, i zdrowe. Ocena ekspercka uzupełniona została opinią mieszkańców ze względu na partycypacyjny charakter projektu. Mieszkańcy mieli możliwość wypowiedzenia się na temat zamieszkiwanego obszaru, dokonanej oceny i proponowanych zmian, których obawiali się najmocniej. Tego typu obawy przede wszystkim posiadały osoby starsze, przyzwyczajone do stanu zastanego.

Analiza urbanistyczna dowiodła, że na jakość badanego obszaru mają wpływ uwarunkowania przestrzenne związane z lokalizacją i segregacją wnętrz urbanistycznych o określonych i zróżnicowanych funkcjach. Istotny wpływ na sposób aranżacji przestrzeni ma również infrastruktura - jej rozbudowa oraz typologia zabudowy oraz jej układ.

Uzupełnieniem analizy urbanistycznej były badania socjologiczne prowadzone przez zespół socjologów z Uniwersytetu Jagiellońskiego. Użyte metody badawcze pozwoliły w wielu aspektach ocenić osiedla jako komfortowe, w których środowisko zbudowane, jego charakter i sposób aranżacji bezpośrednio wpływa na kondycję psycho-fizyczną mieszkańców oraz sposób jego postrzegania i odczuwania.

\section{Literatura}

[1] J.Kobylarczyk, G. Schneider-Skalska, P. Haupt, K. Racoń-Leja, W. Sumlet, P. Tor, Studenckie Koło Naukowe Projektowania Zrównoważonego, Diagnoza funkcjonalno-przestrzenna osiedli: Olsza Iii Ugorka, Politechnika Krakowska, Kraków 2014.

[1] Gehl Jan, Miasta dla ludzi, RAM, Kraków 2014.

[2] Kobylarczyk Ocena jakości środowiska zamieszkania $w$ wybranych miastach województwa podkarpackiego po okresie „transformacji” w pierwszej dekadzie XXI wieku, Politechnika Krakowska, Kraków 2013.

[3] Kobylarczyk J, G. Schneider-Skalska, P. Haupt, K. Racoń-Leja, W. Sumlet, P. Tor, Studenckie Koło Naukowe Projektowania Zrównoważonego, Diagnoza funkcjonalno-przestrzenna osiedli: Olsza Iii Ugorka, Politechnika Krakowska, Kraków 2014.

[4] Montgomery Ch., Miasto szczęśliwe. Jak zmieniać nasze życie, zmienijąc nasze miasta, Wysocki Zamek, Kraków 2015.

[5] Schneider-Skalska G., Design a healthy housing environment. Selected problems, Lap Lambert Academiic Publishing, Saarbrücken 2011.

${ }^{6}$ Gehl J., Miasta dla ludzi, RAM, Kraków 2014, str.25 


\section{THE ISSUE OF COMFORT IN RESIDENTIAL ENVIRONMENT}

\section{S u m m a r y}

Comfort of environment and its impact on the man is a complex issue; therefore it can be examined through the prism of many scientific disciplines. It touches the problems of spatial planning, architecture, urban planning, as well as sociology. Another problem associated with the specified topic is the difficulty of obtaining objective results of the assessment of the quality of residential environment, and consequently, the conclusions allowing to identify the relations that stem from the impact of the environment - its animate and inanimate components on human. The article presents functional and spatial diagnosis made for two housing settlements in Krakow Olsza II and Ugorek. The project was implemented by the team from the Institute of Urban Design, Faculty of Architecture, Cracow University of Technology and commissioned by the City of Krakow as a part of the Pilotage Program for Rehabilitation of Block Building in the City of Krakow. In all phases of the project, expert research were supported by the opinion of residents of the assessed settlements, who took part in workshops and meetings where they were able to present views on the inhabited area, its arrangement, strengths and weaknesses.

Keywords: residential environment, comfort, spatial-functional diagnosis, housing settlement

DOI: $10.7862 / \mathrm{rb} .2016 .272$

Przestano do redakcji: $30.06 .2016 r$.

Przyjęto do druku: 20.12.2016 r. 
